\title{
THE EFFECT OF PIG MANURE FERMENTED BY LARVAE OF HOUSE FLIES ON THE YIELD PARAMETERS OF SUNFLOWERS (Helianthus annus L.)
}

\author{
P. Kováčik, M. Kozánek, P. Takáč, M. Galliková, L. Varga
}

Received: January 22, 2010

\begin{abstract}
KOVÁČIK, P., KOZÁNEK, M., TAKÁČ, P., GALLIKOVÁ, M., VARGA, L.: The effect of pig manure fermented by larvae of house flies on the yield parameters of sunflowers. Acta univ. agric. et silvic. Mendel. Brun., 2010, LVIII, No. 2, pp. 147-154

The effect of fermented pig manure processed on a bed of wooden shavings and fermented for seven days by larvae of house flies on the yield parameters of sunflowers have been investigated on Haplic Luvisol in the pot trial realized in vegetative cage placed on the territory of SAU in Nitra. The experiment consisted of six treatments (0, NPK, Manure ${ }_{1}$, Manure $_{2}$, Manure $_{3}$, Veget). Treatments 0, NPK,

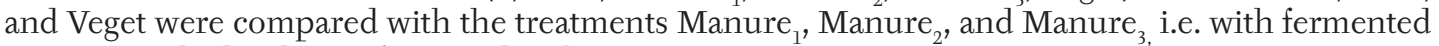
manure applied at doses of 4,6 , and $8 \mathrm{t} \mathrm{ha}^{-1}$.

The results showed that application of fermented manure resulted in statistically significant greater stem thickness, higher leaf chlorophyll content, composites and harvest yield of seeds. The plants appeared healthy. Increasing the doses of fermented manure resulted in greater harvest yield of achenes and fat content in them. The dose of $4 \mathrm{t} \cdot \mathrm{ha}^{-1}$ of fermented manure has proven to be insufficient.

Out of the tested doses of 4, 6 and $8 \mathrm{t} \cdot \mathrm{ha}^{-1}$ of fermented manure the highest achene yield has been achieved at the dose of $8 \mathrm{t}^{\text {.ha }}{ }^{-1}$ but it was lower than the yield of the treatments fertilized by NPK fertilizers or Veget. From the viewpoint of achene yield quality (fat content) out of six variants the best parameters were achieved with the treatment where fermented manure at the dose of $8 \mathrm{t}$.ha ${ }^{-1}$ was applied.

The gathered data point towards the applicability and usefulness of manure processed by larvae of flies in agronomy. It is of note, that the manure fermentation period can be significantly shortened, whereby reducing the storage difficulties.
\end{abstract}

pig manure, fermentation, larvae, domestic fly, sunflowers, fat, chlorophyll

Application of high-quality manure has positive influence on biological, chemical and physical parameters of soil (Marschner, 2005). It is the source of nutrients and organic substances such as cellulose, hemicellulose, lignin, carbohydrates, proteins and amino acids which are essential for fermentation of humus. Annually, it substitutes for about $40 \%$ of mineralized organic substance in the soil. Manure increases the buffering and absorbing capacity of soil. It provides nutrients and growth stimulators such as hippuric acid, uric acid, indolylacetic acid and gonadotropic hormones. Manure also in- fluence formation of soil aggregates. Furthermore, it has a positive effect on the circulation of air and water in the soil and also effects the thermal regulation. It works against the fatigue of the soil and its application facilitates the decomposition of postharvest remnants that can be a source of pathogens (Kováčik, 2009). Manure limits the entry of heavy metals into the food chain (Zaniewicz-Bajkowska et al., 2007), revives the soil biologically (Zaller and Köpke, 2004), mobilizes compounds of nutrients that are difficult to dilute and limits the entry of insoluble compounds of macrobiogenic elements. In 
addition, it plays a role in facilitating the biodegradation of various wastes (Řimovský et al., 1998) and impurities e.g. oil products. In this way manure enhances the absorbing capacity of plants and crops with regards to the nutrients (Lacko-Bartošová et al., 2005). Application of industrial manures of poor quality, wrong timing, dosage or wrong manipulation with them can threaten the environment and affect the quality and yield of harvests (Kiepas-Kokot et al., 2005).

Despite the above mentioned positive effect of natural manures on soil, the effect of its storage (fermentation) on the quality thereof are paid less attention in Slovakia than in the neighboring countries. In effort to resolve this issue and to shorten the storage time i.e. fermentation of stall manure, which typically takes about six months to accomplish if the bed is formed by wooden shavings, was investigated the effect of pig manure produced on a bed of wooden shavings, fermented for seven days by larvae of house fly on the production and quality of phytomass of sunflowers.

\section{MATERIALS AND METHODS}

The pot experiment was conducted in a vegetation cage situated in the area of the Slovak Agricultural
University in Nitra (48 $18^{\circ}$ N, $18^{\circ} 05^{\prime}$ E). Experimental pots were filled with $23.5 \mathrm{~kg}$ of modal brownsoil (Haplic Luvisols), agrochemical characteristics of which are given in Table I and the methods of their determination are added under Table I.

Agrochemical and hygienic-toxicological parameters of used fermented manure are presented in Table II. From the table is evident that heavy metal contents answer the law criteria determining the quality of manure (Code of Laws No. 577/2005, p. 232).

The tested manure was obtained by seeding eggs of house fly into fresh pig manure on a bed of wooden shavings. The hatched larvae processed the manure for seven days and pupated. The pupae were collected; the manure was dried and milled. The color, size of individual parts and water content of the processed manure can be compared to that of black tea. It was loose and of brownish colour.

Detailed description of the process is not included here for patenting purposes; however, Slamečka (1988) has published similar techniques of breeding domestic flies and the process of obtaining pupae.

The experiment had six treatments with five repetitions (Tab. III). It was based on the method of randomized blocks. Approximately midway through the vegetation season was the fifth repe-

I: The basic agrochemical parameters of materials used in the experiment (dry matter)

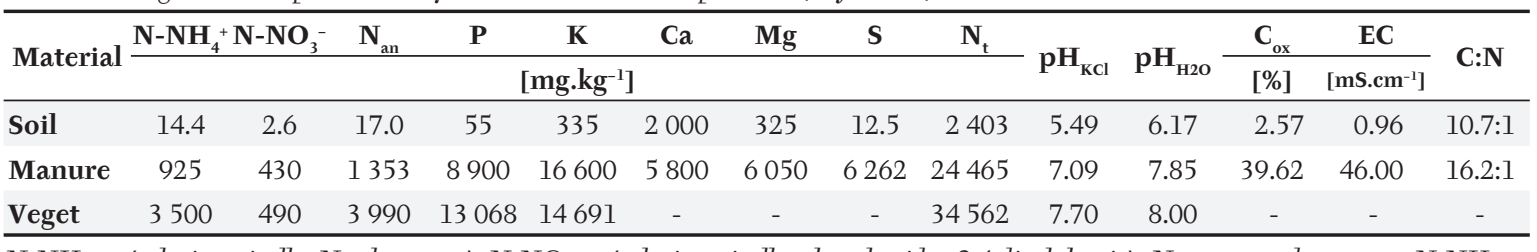

$\mathrm{N}-\mathrm{NH}_{4}{ }^{+}-$(colorimetrically, Nessler agent); $\mathrm{N}-\mathrm{NO}_{3}{ }^{-}-$(colorimetrically, phenol acid - 2,4 disulphonic); $\mathrm{N}_{a n}-\mathrm{counted}$ as a sum $\mathrm{N}-\mathrm{NH}{ }_{4}^{+}+$ $\mathrm{N}-\mathrm{NO}_{3}^{-} ; \mathrm{P}-($ colorimetrically, Mehlich II), K - (flame photometry, Mehlich II); Mg - (atomic absorption spectrophotometry, Mehlich II), S (nephelometry ammonium acetate), $\mathrm{N}_{t}-$ Kjeldahl, $\mathrm{pH}_{\mathrm{KCL}}-(1,0 \mathrm{M} \mathrm{KCl}), \mathrm{pH}_{\mathrm{H} 2 \mathrm{Ol}}-\left(\mathrm{H}_{2} \mathrm{O}\right), \mathbf{C}_{\mathrm{ox}}-($ as oxidizable carbon - Tjurin), EC - electric conductivity

II: Comparison of parameters of the tested fertilizer with standards required by law (Code of Laws No 577/2005)

\begin{tabular}{|c|c|c|}
\hline Parameters & $\begin{array}{c}\text { Values declared by law } \\
\text { No } 577 / 2005\end{array}$ & Measured values \\
\hline pH (10 \% water suspension) & $6.5-8.5$ & 7.85 \\
\hline Dried content & $\min .40 \%$ & $87.8 \%$ \\
\hline Burnable dried content & $\min .50 \%$ & $77.0 \%$ \\
\hline Total nitrogen as a $\mathbf{N}$ total in dried content & $\min .1 .0 \%$ & $2.45 \%$ \\
\hline Total phosphorus as $\mathrm{P}_{2} \mathrm{O}_{5}$ in dried content & $0.5 \%$ & $3.96 \%$ \\
\hline Total potassium as $\mathrm{K}_{2} \mathrm{O}$ in dried content & $0.5 \%$ & $2.11 \%$ \\
\hline Calcium as $\mathrm{Ca}$ in dried content & $1.0 \%$ & $1.91 \%$ \\
\hline Magnesium as Mg in dried content & $0.5 \%$ & $0.88 \%$ \\
\hline Elements under $20,0 \mathrm{~mm}$ & $100.0 \%$ & $100.0 \%$ \\
\hline Cd in $100 \%$ of dry matter & $2 \mathrm{mg} \cdot \mathrm{kg}^{-1}$ & $0.725 \mathrm{mg} \cdot \mathrm{kg}^{-1}$ \\
\hline As in $100 \%$ of dry matter & $10 \mathrm{mg} \cdot \mathrm{kg}^{-1}$ & $0.57-1.13 \mathrm{mg} \cdot \mathrm{kg}^{-1}$ \\
\hline $\mathrm{Hg}$ in $100 \%$ of dry matter & $1 \mathrm{mg} \cdot \mathrm{kg}^{-1}$ & $0.09-0.036 \mathrm{mg} \cdot \mathrm{kg}^{-1}$ \\
\hline Cr in $100 \%$ of dry matter & $100 \mathrm{mg} \cdot \mathrm{kg}^{-1}$ & $54.09 \mathrm{mg} \cdot \mathrm{kg}^{-1}$ \\
\hline Ni in $100 \%$ of dry matter & $50 \mathrm{mg} \cdot \mathrm{kg}^{-1}$ & $12.66 \mathrm{mg} \cdot \mathrm{kg}^{-1}$ \\
\hline $\mathrm{Pb}$ in $100 \%$ of dry matter & $100 \mathrm{mg} \cdot \mathrm{kg}^{-1}$ & $5.20-10.54 \mathrm{mg} \cdot \mathrm{kg}^{-1}$ \\
\hline
\end{tabular}


III: Experimental treatments and fertilizer doses

\begin{tabular}{|c|c|c|c|c|c|c|c|c|}
\hline \multicolumn{3}{|r|}{ Treatment } & \multicolumn{4}{|c|}{ Dose of fertilizer } & \multicolumn{2}{|c|}{ Dose of $\mathbf{N}$} \\
\hline \multirow{2}{*}{ No. } & \multirow{2}{*}{ designation } & \multirow{2}{*}{ specification } & \multirow{2}{*}{ t.ha $\mathbf{a}^{-1}$} & \multicolumn{3}{|c|}{ kg.ha-1 } & \multirow{2}{*}{$\begin{array}{r}\text { inorganic } \\
\text { kg.ha } \\
\end{array}$} & \multirow{2}{*}{ total } \\
\hline & & & & LAD & SP & $\mathrm{KCl}$ & & \\
\hline 2 & NPK & Mineral fertilizers - N, P, K & - & 300 & 417 & 357 & 81 & 81 \\
\hline 3 & Manure $_{1}$ & Manure fermented by house fly larvae & 4 & - & - & - & 5.4 & 86 \\
\hline 5 & Manure $_{3}$ & Manure fermented by house fly larvae & 8 & - & - & - & 10.8 & 172 \\
\hline 6 & Veget & Biofertilizer produced from pharmaceutical waste & 4.3 & - & - & - & 17.2 & 129 \\
\hline
\end{tabular}

LAD - ammonium nitrate with dolomite, SP - superphosphate, $\mathrm{KCl}$ - potassium chloride

tition used for collection of crop and soil samples and from there the experiments had four repetitions. Treatments 1,2 , and 6 were used for comparisons of efficiency of the fermented manure. In treatment 1 , no manures were used. In treatment 2 , we used NPK fertilizers and the doses were calculated based on the contents of $\mathrm{N}_{\mathrm{an}}$ and the available $\mathrm{P}$ and $\mathrm{K}$ in the soil and the need for a planned harvest of 3.5 t.ha ${ }^{-1}$ of sunflowers. Biomanure Veget was applied in treatment 6 for control since this manure was awarded the Golden Crescent Prize of the Slovak Ministry of Agriculture. Veget was produced from pharmaceutical wastes in Biotika company in Slovenská L'upča.

Treatments 3, 4, and 5 were aimed to test the gradual increase in dose of fermented pig manure. Fermented pig manure at a dose of 6 t.ha $^{-1}$ (treat. 4) carried the same amount of $\mathrm{N}$ as Veget at a dose of 4.3 t.ha- ${ }^{-1}$ (treat. 6), however, the contents of inorganic nitrogen differed for the two (Tab. III). The dose of 8 t.ha $^{-1}$ of manure (treat. 5) represented the maximal allowed nitrogen dosage (170 kg.ha-1) according to the nitrate regulations established by the government. This legislative rule determined that higher rates of fermented manure were not tested.

The model crop was chosen to be sunflower, variety PR 63 A 90. Seven seeds were seeded per planter and were subsequently covered with sterile sand (1.5 kg). Thus, each planter weighted $25 \mathrm{~kg}$. The average number of plants was unified to 4 plants per planter. Soil humidity was maintained at $60 \%$ FWC (full water capacity) by watering with distilled water on regular basis (on average one-two times per day).

During growing season, was measured the height of plants, stem circumference, whole chlorophyll content by Šesták and Čatský (1966) method and weight of the above ground phytomass. The health of the vegetation and the time to bloom were assessed as well. On $130^{\text {th }}$ day from sowing the plants were collected and assessed for diameter of flower composites, achene yield and their fat content by Soxlet method. Acquired results were processed by mathematical and statistical method, by analysis of variance and linear regression analysis using Statgraphics PC program, version 5.0.

\section{RESULTS AND DISCUSSION}

Utilization of pig manure fermented by larvae of house fly, as well as Veget and NPK demonstrated a statistically significant effect on the production of above-ground phytomass of sunflowers (Tab. IV). During the initial stages of growth (38 days after sowing), the applied manures significantly facilitated growth. This was demonstrated by the observation of the smallest vegetation height in the unfertilized treatment 1 (Tab. V). Increasing rate of fermented manure augmented the height of plants (treat. 3, 4, 5 versus treat. 1). The tallest plants were found in treatment 5 where the dose of fermented manure was highest $\left(8 \mathrm{t}^{-h \mathrm{~h}^{-1}}\right)$. During this stage of growth, Veget did not show such significant effect on vegetation height as fermented manure (treat. 6 vs. treat. 4; Tab. V).

The thinnest stems ( $55^{\text {th }}$ day of the experiment) were also observed in treatment 1 (Tab. IV) and the differences between fertilized and unfertilized treatments were statistically significant. The thickest stems were documented in treatment 2 , where the NPK fertilizers were applied. The differences stem thickness between treatment 2 and the other

IV: The effect of sources of variability on sunflower phytomass

\begin{tabular}{|c|c|c|c|c|c|c|}
\hline \multirow{2}{*}{$\begin{array}{c}\text { Source } \\
\text { of variability }\end{array}$} & \multirow[b]{2}{*}{ d.f. } & \multicolumn{2}{|c|}{ F-calculated } & \multirow[b]{2}{*}{ d.f. } & \multicolumn{2}{|c|}{ F-calculated } \\
\hline & & $\begin{array}{c}\text { Heigth of plants } \\
38^{\circ}\end{array}$ & Circuit of stem 55 & & $\begin{array}{c}\text { Heigth of plants } \\
63^{\circ}\end{array}$ & $\begin{array}{l}\text { Phytomass/pot } \\
\text { (100\% dm) 63. }\end{array}$ \\
\hline Treatment & 5 & $6.004^{++}$ & $6.964^{++}$ & 5 & $755.901^{++}$ & $894.156^{++}$ \\
\hline Repetition & 4 & 0.928 & 0.549 & 3 & 1.395 & 0.395 \\
\hline Residual & 20 & & & 15 & & \\
\hline Total & 29 & & & 23 & & \\
\hline
\end{tabular}

d.f. - degree of freedom, - days from seeding, dm - dry matter 
treatments were statistically significant except for the comparison with the treatment where the highest concentration of fermented manure was used.

In the second half of the vegetation period $(63$ days from sowing) the effects of fertilization started to differ. Undernourished sunflowers became taller and thinner, had fewer leaves and longer internodial distances, compared to those living in better conditions. The leaves had smaller blades and were lighter. Unfertilized treatment 1 was statistically significantly the tallest and had developed only 6 levels of leaves. Treatments 3, 4, 5, and 6 had 7 levels of leaves and treatment 2 (mineral NPK fertilizers) had 8-9 leave levels. Concurrently, in the unfertilized treatment 1 we observed the smallest amount of phytomass, whereas the greatest was present in treatment 2 (Tab. V). The phytomass was shown to increase with increasing dose of fermented manure. The observation that undernourished sunflowers are taller has been made by Kováčik (2007). This is in contrary to several other reports in the literature stating that undernourished plants are small, falling behind in growth (Bould et al., 1983; Bergmann, 1986).
The effect of trial treatments on the whole chlorophyll content in sunflower leaves was changing during the vegetation period (Tab. VI). There occurred one exception - treatment 1 (unfertilized) with the statistically lowest chlorophyll content. During the first sample taking the highest chlorophyll content had the treatments where $8 \mathrm{t}^{-h \mathrm{~h}^{-1} \text { of fer- }}$ mented manure were applied. In the second, third and fourth takings the highest content of chlorophyll was determined in the treatment fertilized by Veget. On visual inspection, the leaves of all variants were light green to deep green in color. The lightest were present in treatment 1 while the darkest were observed in treatment $6(1<3 \leq 4<5 \leq 2 \leq 6)$.

In eleven out of twelve cases it was found that the chlorophyll contents increased with gradual increase in dosage of fermented pig manure. This confirms the positive effect of its use on chlorophyll content (Tab. VI).

The positive relation between the chlorophyll content and the yield of grown plants has been confirmed. The intensity of this dependence changed in different phases of sunflower growth and different time of leaves taking. At the beginning of the vegeta-

$\mathrm{V}$ : The effect of experimental treatments on production of phytomass in the first half of vegetation period

\begin{tabular}{|c|c|c|c|c|c|c|c|c|c|}
\hline & \multirow{4}{*}{$\begin{array}{l}\text { Treatment } \\
\text { specification }\end{array}$} & \multicolumn{2}{|c|}{ Height of plants } & \multicolumn{2}{|c|}{ Circuit of stem } & \multicolumn{2}{|c|}{ Height of plants } & \multicolumn{2}{|c|}{$\begin{array}{c}\text { Phytomass/pot } \\
(100 \% \text { dry })\end{array}$} \\
\hline \multirow{3}{*}{$\mathbf{n}$} & & \multicolumn{8}{|c|}{ days from seeding } \\
\hline & & \multicolumn{2}{|c|}{38} & \multicolumn{2}{|c|}{55} & \multicolumn{4}{|c|}{63} \\
\hline & & $\mathbf{c m}$ & order & $\mathbf{c m}$ & order & $\mathrm{cm}$ & order & g & order \\
\hline 1 & Without fertilizers & $31.1 \mathrm{a}$ & 6 & $3.65 \mathrm{a}$ & 6 & $99 \mathrm{e}$ & 1 & $40 \mathrm{a}$ & 6 \\
\hline 2 & NPK fertilizers & $36.4 \mathrm{bc}$ & 3 & $4.56 \mathrm{~d}$ & 1 & $85 \mathrm{c}$ & 5 & $130 \mathrm{f}$ & 1 \\
\hline 3 & 4 t.ha-1 fer. man. $\vee$ & $35.0 \mathrm{bc}$ & 4 & $4.02 \mathrm{~b}$ & 5 & $88 \mathrm{~d}$ & 2 & $95 \mathrm{c}$ & 4 \\
\hline 4 & 6 t.ha-1 fer. man. & $36.7 \mathrm{bc}$ & 2 & $4.09 \mathrm{bc}$ & 3 & $84 \mathrm{~b}$ & $3-4$ & $110 \mathrm{~d}$ & 3 \\
\hline 5 & 8 t.ha-1 fer. man. & $37.7 \mathrm{c}$ & 1 & $4.35 \mathrm{~cd}$ & 2 & $84 \mathrm{~b}$ & $3-4$ & $115 \mathrm{e}$ & 2 \\
\hline 6 & 4.3 t.ha-1 Veget & $34.2 \mathrm{~b}$ & 5 & $4.05 \mathrm{bc}$ & 4 & $79 a$ & 6 & $90 \mathrm{~b}$ & 5 \\
\hline \multicolumn{2}{|c|}{ LSD $_{0,05}$} & \multicolumn{2}{|c|}{2.846} & \multicolumn{2}{|c|}{0.347} & \multicolumn{2}{|c|}{0.742} & \multicolumn{2}{|c|}{3.151} \\
\hline \multicolumn{2}{|c|}{ LSD $_{0,01}$} & \multicolumn{2}{|c|}{3.882} & \multicolumn{2}{|c|}{0.474} & \multicolumn{2}{|c|}{1.027} & \multicolumn{2}{|c|}{4.356} \\
\hline
\end{tabular}

$\checkmark$ - fermented manure, - the same letters denote that there are not statistically significant differences between average values, LSD - limit of significant difference at the level $\alpha=0.05$ and $\alpha=0.01$

VI: The whole chlorophyll content (chlorophyll $a+b$ )

\begin{tabular}{|c|c|c|c|c|c|}
\hline \multicolumn{2}{|r|}{ Treatment } & \multicolumn{4}{|c|}{ Date of leaves collection/days from seeding } \\
\hline \multirow{2}{*}{ number } & \multirow{2}{*}{ specification } & 31. may/44 & 31. may/44 & 31. may/44 & 21. jun/65 \\
\hline & & \multicolumn{4}{|c|}{ mg.l $\mathbf{l}^{-1}$} \\
\hline 1 & Without fertilizers & $4.416 \mathrm{a}$ & $6.534 \mathrm{a}$ & $15.997 \mathrm{a}$ & $15.427 \mathrm{a}$ \\
\hline 2 & NPK fertilizers & $5.324 \mathrm{~b}$ & $7.156 \mathrm{~b}$ & $19.303 \mathrm{e}$ & $16.273 \mathrm{c}$ \\
\hline 3 & 4 t.ha ${ }^{-1}$ fer. man. ${ }^{\vee}$ & $6.471 \mathrm{c}$ & $7.518 \mathrm{c}$ & $16.267 \mathrm{~b}$ & $15.711 b$ \\
\hline 4 & 6 t.hat ${ }^{-1}$ fer. man. & $6.674 \mathrm{~d}$ & $7.194 \mathrm{~b}$ & $16.635 \mathrm{c}$ & $15.848 \mathrm{~b}$ \\
\hline 5 & 8 t.ha ${ }^{-1}$ fer. man. & $6.934 \mathrm{e}$ & $7.527 \mathrm{c}$ & $17.838 \mathrm{~d}$ & $16.244 \mathrm{c}$ \\
\hline 6 & 4.3 t.ha ${ }^{-1}$ Veg. & $6.626 \mathrm{~d}$ & $7.643 \mathrm{c}$ & $19.370 \mathrm{e}$ & $17.008 \mathrm{~d}$ \\
\hline LSD $_{0.05}$ & & 0.06779 & 0.18175 & 0.18034 & 0.18098 \\
\hline LSD $_{0.01}$ & & 0.09371 & 0.25125 & 0.2493 & 0.25019 \\
\hline
\end{tabular}

$\checkmark$-fermented manure, LSD - limit of significant difference at the level $\alpha=0.05$ and $\alpha=0.01$ 
tion (end of May) it was insignificant and in June and July highly evidential (Table VII).

Tested fertilizers had influence on the date of flowering as well. Sunflowers in NPK treatment flowered the first (July $1^{\text {st }}$ ). Four days later, plants from treatments 4, 5 and 6 (treatments treated with fermented manure in doses 6 and 8 t.hat ${ }^{-1}$ and treatment treated with Veget) started to flower. Six days later flowered sunflowers treated with the lowest dose of fermented manure $\left(4 \mathrm{t} \cdot \mathrm{ha}^{-1}\right)$. Treatment with no fertilizer flowered 11 days later compared with treatment fertilized by NPK.

The fact that the greatest concentration of inorganic nitrogen was added to the soil in treatment 2 (Tab. III) resulted in formation of greatest composites and subsequently in greatest harvest yields (Tab. VII). The relationship between the size of composite and achene harvest yields (in $100 \%$ dry matter) was linear and of significantly positive correlation $\left(\mathrm{r}=0.8681^{++}\right)$.

The differences in harvest yields of achenes were statistically significant not only between treatment 2 (NPK fertilizers) and others but also between treatment 1 (unfertilized) and others.

Gradual increases in doses of tested fertilizer (treat. 3 versus treat. 4 versus treat. 5) resulted in formation of greater composites and subsequently greater harvest yields. However, the differences did not reach the level observed when Veget was used, which was highly statistically significant.
Remarkable is the positive correlation between the harvest yield of achenes (in $100 \%$ dry matter) and the fat content therein $\left(r=0.6399^{++}\right)$. In other words, we noted that with increasing dose of fermented pig manure the achenes were not only more abundant in number but also in contents of fat. This observation is in contrast to the findings of Özer et al. (2004) who reported that with increasing dose of $\mathrm{N}$, the fat content decreases. Škarpa and Lošák (2008) found out that achene yields and oil production was increased after nitrogen application.

Of all studied treatments, we measured the greatest fat content in the treatment where the highest concentration of fermented manure was used (up to 8 t.ha- ${ }^{-1}$ ). Differences between this treatment and others were highly statistically significant.

Production of fat per pot was in correlation $(r=$ $0.6885^{++}$) with the rate of applied inorganic nitrogen. Increase of applied $\mathrm{N}$ rates (Tab. III) caused the elevation of fat production (Tab. VIII).

These findings demonstrate the positive effect of fermented manure on qualitative parameters of sunflowers, which along with its beneficial effect on increasing harvest yields, creates foundation for its successful application in agricultural industry. Additionally, this study presents an interesting solution to one of the critical problems in agriculture i.e. disposal of high-volumes of manure and reintroduction of the nutrients into the food chain by a novel environment-friendly technique of fermentation using larvae of house fly.

VII: Dependence of sunflower achene yields on chlorophyll content in leaves expressed by linear regression analysis ( $r$ )

\begin{tabular}{|c|c|c|c|c|c|}
\hline \multicolumn{2}{|c|}{ Parameter } & \multicolumn{4}{|c|}{ Sampling/date of sampling } \\
\hline Dependent & independent & I./31. may & II./7.jun & III./14. jun & IV./21.jun \\
\hline $\begin{array}{l}\text { The yield of achene } \\
\text { (100\% dry matter) }\end{array}$ & The whole chlorophyll & \multicolumn{4}{|c|}{$\mathbf{r}$} \\
\hline
\end{tabular}

VIII: The harvest parameters of sunflower

\begin{tabular}{|c|c|c|c|c|c|c|c|c|}
\hline \multicolumn{2}{|c|}{ Treatment } & \multirow{2}{*}{$\begin{array}{c}\begin{array}{c}\text { Flower head } \\
\text { diameter }\end{array} \\
\mathrm{cm} \\
\end{array}$} & \multicolumn{2}{|c|}{$\begin{array}{c}\text { Yield of seeds } \\
\text { (100\% dry mass) }\end{array}$} & \multicolumn{2}{|c|}{$\begin{array}{c}\text { Fat content } \\
\text { (92 \% dry mass) }\end{array}$} & \multicolumn{2}{|c|}{ Fat production } \\
\hline number & specification & & g/pot & order & $\%$ & order & g/pot & order \\
\hline 1 & Without fertilizers & $6.37 \mathrm{a}$ & $21.50 \mathrm{a}$ & 6 & $31.70 \mathrm{a}$ & 6 & $6.27 \mathrm{a}$ & 6 \\
\hline 2 & NPK fertilizers & $9.37 \mathrm{c}$ & $55.09 \mathrm{~d}$ & 1 & $42.30 \mathrm{c}$ & 4 & $21.44 \mathrm{e}$ & 1 \\
\hline 3 & 4 t.ha ${ }^{-1}$ fer. hn. & $8.18 \mathrm{~b}$ & $37.15 \mathrm{~b}$ & $4-5$ & $37.33 \mathrm{~b}$ & 5 & $12.76 \mathrm{~b}$ & 5 \\
\hline 5 & 8 t.ha-1 fer. hn. & $8.32 \mathrm{~b}$ & $39.53 \mathrm{~b}$ & 3 & $47.25 \mathrm{~d}$ & 1 & $17.18 \mathrm{~cd}$ & 3 \\
\hline 6 & 4.3 t.hat ${ }^{-1}$ Veg. & $8.74 \mathrm{bc}$ & $44.26 \mathrm{c}$ & 2 & $44.83 \mathrm{~cd}$ & 2 & $18.25 \mathrm{~d}$ & 2 \\
\hline LSD $_{0.05}$ & & 0.953 & \multicolumn{2}{|c|}{4.271} & \multicolumn{2}{|c|}{3.031} & \multicolumn{2}{|c|}{2.387} \\
\hline LSD $_{0.01}$ & & 1.317 & \multicolumn{2}{|c|}{5.904} & \multicolumn{2}{|c|}{4.190} & \multicolumn{2}{|c|}{3.300} \\
\hline
\end{tabular}

LSD - limit of significant difference at the level $\alpha=0.05$ and $\alpha=0.01$ 


\section{CONCLUSION}

The results of this study have shown that using the pig manure fermented by larvae of house fly for 7 days at doses 4,6 and 8 t.ha ${ }^{-1}$ :

- is a simple and efficient technique for increasing harvest yields. This technique does not require any special equipment. The heavy metal content is negligible and due to low water content (approxim. 12\%) the fertilizer is easy to store,

- growth is intensified during the initial stages of growth resulting in thicker and firmer stems,

- had positive effect on the weight of the above-ground phytomass and chlorophyll content. The plants appeared healthy and were greener in comparison to others. During the blossoming period, the sunflowers were smaller and had denser foliage, bloomed earlier, and created greater composites,

- the yield of achene and its fat content increase.

Out of the tested doses of 4, 6 and 8 t.ha $^{-1}$ of fermented manure the highest achene yield has been achieved at the dose of 8 t.ha-1 but it was lower than the yield of the variants fertilized by NPK fertilizers or Veget. From the viewpoint of achene yield quality (fat content) out of six variants the best parameters were achieved with the variant where fermented manure at the dose of $8 \mathrm{t}^{-h a^{-1}}$ was applied. Positive relations between yield quantity and content of chlorophyll in leaves as well as $\mathrm{N}$ rates and fat production of growing area were confirmed.

All findings of this study show that using this technique it is possible to shorten the fermentation time, thereby significantly decreasing the burden on fertilizer storage facilities.

\section{SÚHRN}

Účinok prasacieho hnoja fermentovaného larvami muchy domácej na úrodové parametre slnečnice ročnej

V nádobovom pokuse realizovanom vo vegetačnej klietke nachádzajúcej sa v areáli SPU v Nitre bol zistovaný vplyv prasacieho hnoja (vyrobeného na pilinovej podstielke a fermentovaného 7 dní larvami muchy domácej), na úrodové parametre slnečnice ročnej. Overovaný hnoj sa získal tak, že do čerstvého vyhrnutého prasacieho hnoja s pilinovou podstielkou boli vložené vajíčka muchy domácej. Vyliahnuté larvy ho 7 dní spracovávali. Následne sa zakuklili. Kukli boli pozbierané, hnoj vysušený a pomletý. Takto spracovaný hnoj svojim zafarbením, vel'kostou jednotlivých častí a obsahom vody pripomínal čierny čaj. Bol sypký, hnedastej farby. Parametre hnoja vyhovovali kritériám organických hnojív určených zákonom Z. z. č. 577/2005.

Pokus mal 6 variantov a bol založený metódou znáhodnených blokov. Varianty l, 2 a 6 slúžili k porovnaniu účinnosti fermentovaného hnoja. Na variante 1 neboli aplikované žiadne hnojivá, na variante 2 boli aplikované priemyselné NPK hnojivá, pričom dávky priemyselných hnojív boli vypočítané na základe rešpektovania obsahu $\mathrm{N}_{\text {an }}$ a prístupného $\mathrm{P}, \mathrm{K} v$ pôde a potreby NPK pre plánovanú úrodu 3,5 t.ha ${ }^{-1}$ slnečnice. Na variante 6 bol aplikovaný biokompost Veget ako porovnávacie kvalitné, avšak relatívne drahé hnojivo.

Na variantoch č. 3, 4 a 5 sa testovali stupňované dávky fermentovaného prasacieho hnoja. Dávka 6 t.ha-1 prasacieho fermentovaného hnoja (var. 4) vnášala rovnaké množstvo celkového $\mathrm{N}$ ako Veget v dávke 4,3 t.ha-1 (var. 6), avšak obsahy anorganického dusíka boli v uvedených hnojoch rôzne. Na variante 4 ( 6 t.ha $^{-1}$ fer. hnoja) bola aplikovaná cca $1 \frac{1}{2}$ anorganického dusíka $\left(\mathrm{N}_{\mathrm{an}}\right)$ v porovnaní $\mathrm{s}$ variantom 6 (Veget) a iba 1/10 z množstva aplikovaného na variante 2 (NPK). Dávka 8 t.ha ${ }^{-1}$ hnoja (var. 5) reprezentovala maximálnu dávku dusíka $\left(170 \mathrm{~kg} \cdot h \mathrm{~h}^{-1} \mathrm{~N}\right)$ povolenú v zranitel'ných územiach SR podl'a platnej nitrátovej smernice.

Z dosiahnutých výsledkov vyplynulo, že aplikácia fermentovaných hnojov v porovnaní s nehnojeným variantom rezultovala v štatisticky preukazne hrubšie steblá, vyšší obsah chlorofylu v listoch, vo väčšie úbory a vyššie úrody. Rastliny slnečníc pôsobili zdravo. So stupňovanou dávkou fermentovaného hnoja sa zvyšovala úroda nažiek a obsah tuku v nich. Z testovaných dávok 4, 6 a 8 t.ha ${ }^{-1}$ fermentovaného hnoja sa najvyššia úroda nažiek dosiahla pri dávke 8 t.ha ${ }^{-1}$, tá však bola nižšia ako na variante hnojenom NPK hnojivami, resp. na variante hnojenom Vegetom. Z hl'adiska kvality úrody nažiek (obsah tuku) sa zo všetkých 6-tich variantov najlepšie parametre dosiahli na variante kde bol aplikovaný fermentovaný hnoj v dávke 8 t.ha ${ }^{-1}$.

So stupňovanou dávkou fermentovaného prasacieho hnoja sa zvyšoval obsah celkového chlorofylu v listoch slnečníc. Potvrdil sa kladný vztah medzi obsahom chlorofylu a úrodou pestovaných rastlín, pričom sila tejto závislosti sa menila v závislosti od rastovej fázy slnečníc, od termínu odberu listov. Na začiatku vegetácie (koniec mája) bola nesignifikantná a v mesiacoch jún a júl bola vysoko preukazná.

Produkcia tuku na nádobu korelovala $\left(r=0,6885^{++}\right)$s výškou aplikovaného anorganického dusíka. $\mathrm{S}$ rastom aplikačných dávok $\mathrm{N}$ rástla produkcia tuku. 
Získané poznatky o účinkoch fermentovaného hnoja na výšku a kvalitu produkcie nažiek slnečnice vytvárajú predpoklad pre jeho úspešné uplatnenie v pol'nohospodárskej praxi. I ked' predmetom výskumu nebola samotná technológia výroby hnoja, je možné konštatovat', že fermentácia hnoja larvami muchy domácej je perspektívnym spôsobom riešenia problematiky spracovania vel'koobjemových skládok hnoja.

prasací hnoj, fermentácia, larva, mucha domáca, slnečnica, tuk, chlorofyl

Acknowledgements

This work has been supported by grant projects VEGA No. 1/4418/07, VEGA No. 1/0654/10 and Ecodiptera Life.

\section{REFERENCES}

BERGMANN, W., 1986: Farbatlas - Ernährungsstörungen bei Kulturpflanzen. Jena: VEB Gustav Fischer Verlag, 2. erweiterte auflage, $306 \mathrm{p}$.

BOULD, C., HEWITT, E. J., NEEDHAM, P, 1983: Diagnosis of mineral disorders in plants. Volume 1, Principles. Her Majesty's stationery office, London, 95 p. ISBN 0112408052.

KIEPAS-KOKOT, A., DUSZA, A., ZABLOCKI, Z., HURY, G., 2005: Mercury contamination of selected organic wastes, composts and vermicompost. Ecological chemistry and engineering, 12: 1-2, p. 71-75.

KOVÁČIK, P., 2007: Výživa a úroveň hnojenia rastlin (Nutrition and level of plant fertilizing). Edícia Agroservis, Nitra: ÚVTIP, 96 p. ISBN 978-80-89088-59-1.

KOVÁČIK, P., 2009: Výživa a systémy hnojení rostlin (Nutrition and systems of plant fertilizing). České Budějovice: Kurent s. r. o., 109 p., ISBN 978-80-87111-16-1.

LACKO-BARTOŠOVÁ, M., CAGÁŇ, L., ČUBOŇ, J., KOVÁČ, K., KOVÁČIK, P., MACÁK, M., MOUDRÝ, J., SABO, P., 2005: Udrüatelné a ekologické pol'nohospodárstvo (Sustainable and ecological agriculture). Nitra: SPU, 575 p., ISBN 80-8069-556-3.

MARSCHNER, H., 2005: Mineral nutrition of higher plants. Sec. ed. Elsevier Academic press, London, 889 p. ISBN 0-12-473543-6.

ÖZER, H., POLAT, T., ÖZTÜRK, E., 2004: Response of irrigated sunflower (Helianthus annuus L.) hybrids to nitrogen fertilization: growth, yield and yield components. Plant, soil and environment, 50: 5 , p. 205-211.

ŘIMMOVSKÝ, K., BAUER, F., BOHÁČEK, Z., LINHARTOVÁ, M., TOUL, J., 1998: Effect of pig slurry on increase of biodegradation of petroleum products in soil. Rostlinná výroba, 44: 7, p. 325-330.
SLAMEČKA, J., 1988: Produkcia kŕmnych bielkovín prostredníctvom lariev a kukiel muchy domácej $\mathrm{v}$ hydinovom truse (Production of feed proteins by means of larvae and pupae of domestic fly in poultry droppings). Kandidátska dizertačná práca (PhD. Thesis). Nitra: VÚŽV, 160 p.

ŠESTÁK, Z., ČATSKÝ, J., 1966: Metody studia fotosyntetické produkce rostlin (Methods of photosynthetic plant production study). Praha: Academia. 394 p.

ŠKARPA, P., LOŠÁK, T., 2008: Changes in selected production parameters and fatty acid composition of sunflower (Helianthus annus, L.). In: Acta Universitatis Agriculturae et Silviculturae Mendelianae Brunensis, 56: 5, p. 203-210.

ZALLER, J. G., KÖPKE, U., 2004: Effects of traditional and biodynamic farmyard manure amendment on yields, soil chemical, biochemical and biological properties in a long-term field experiment. Biology and fertility of soils, 40: 4, p. 222-229.

ZANIEWICZ-BAJKOWSKA, A., ROSA, R., FRANCZUK, J., KOSTERNA, E., 2007: Direct and secondary effect of liming and organic fertilization on cadmium content in soil and in vegetables. In: Plant Soil and Environ., 53: 11, p. 473-481.

ZBIERKAZÁKONOV, č. 577/2005, čiastka 232, 2005: Vyhláška Ministerstva pôdohospodárstva Slovenskej republiky z 23. mája 2005, ktorou sa ustanovujú typy hnojív, zloženie, balenie a označovanie hnojív, analytické skúšania hnojív, rizikové prvky, ich limitné hodnoty pre jednotlivé skupiny, prípustné odchýlky a limitné hodnoty pre hospodárske hnojivá (Code of Laws No. 577/2005, part 232. (2005): Regulation of Ministry of Agriculture of Slovak Republic issued on the $23^{\text {rd }}$ of May 2005, by which the types of fertilizers, composition, packing and designation of fertilizers, analytical testing of fertilizers, risky elements and their limiting values for respective groups of fertilizers are determined).

\section{Address}

doc. Ing. Peter Kováčik, CSc., Ing. Martina Galliková, Ing. Ladislav Varga, Ph.D., Slovenská pol'nohospodárska univerzita v Nitre, Fakulta agrobiológie a potravinových zdrojov, Katedra agrochémie a výživy rastlín, Tr. A. Hlinku 2, 94976 Nitra, Slovensko, e-mail: Peter.Kovacik@uniag.sk, maartinaa@inMail.sk, ladislav. varga@uniag.sk, RNDr. Milan Kozánek, CSc., RNDr. Peter Takáč, CSc. Ustav zoológie, Sekcia molekulárnej a aplikovanej zoológie, Slovenská akadémia vied, Dúbravská cesta 9, 84506 Bratislava, e-mail: milan.kozanek@savba.sk, peter.takac@savba.sk 
